\title{
THE IMPACT OF OPEN DUMPING METHOD IN NGIPIK LANDFILL INVESTIGATED WITH ELECTRICAL RESISTIVITY TOMOGRAPHY (ERT) AND VERY LOW-FREQUENCY ELECTROMAGNETIC (VLF-EM)
}

\author{
${ }^{*}$ Nila Sutra ${ }^{1}$, Ria Asih Aryani Soemitro ${ }^{1}$, ${ }^{\text {Dwa Desa Warnana }}{ }^{1}$, Toshifumi Mukunoki ${ }^{2}$, Januarti Jaya \\ Ekaputri ${ }^{1}$, Ahmad Qomaruddin Arsyadi ${ }^{1}$, and Khairul Yadi ${ }^{1}$
}

${ }^{1}$ Faculty of Civil, Planning and Geo Engineering, Institut Teknologi Sepuluh Nopember, Indonesia; ${ }^{2}$ Faculty of Advanced Science and Technology, Kumamoto University, Japan

*Corresponding Authors, Received: 30 Aug. 2019, Revised: 28 Jan. 2020, Accepted: 21 Feb. 2020

\begin{abstract}
The open dumping is a dangerous yet common landfilling method in the developing countries. In Indonesia, 90\% of landfills across the country still apply the open dumping method. A minimum construction cost and time, by disposing the waste directly to the ground pit, make the open dumping method as the easiest waste disposing option. However, this method potentially causes uncontrolled leachate deployment which result in groundwater contamination. To assess the risk of this method, this research employed geophysical measurements in Ngipik landfill, Gresik - East Java, which has been operated since 2002 with open dumping method. The geophysical measurement is the quickest method to investigate contamination mapping in a large area without drilling many wells to investigate water contamination. Very low-frequency electromagnetic (VLF-EM) method is one of the most used methods to investigate groundwater contamination, because of the easy operating and flexible equipment, while the electrical resistivity tomography (ERT) investigation is a quick and excellent method to map the contamination in the landfill area. In this study, 10 profiles of VLF-EM and 7 profiles of ERT investigation are employed to evaluate the leachate deployment in Ngipik landfill area. A 3D image of both methods is presented in the dry and rainy season to map the leachate plume in the landfill area. A laboratory-scale investigation is conducted to interpret the leachate resistivity on the field. The result shows that the leachate has been deployed up to 25 meters in some profiles nearby the waste mound. The water quality of surrounded wells has also affected by the leachate agreed to the geophysical method. Finally, this research proves that, VLF-EM and ER methods are effective to analyze the leachate plume in the landfill area.
\end{abstract}

Keywords: VLF Electromagnetic, Electrical Resistivity Tomography, Landfill, Leachate, Contamination.

\section{INTRODUCTION}

The open dumping method is a major cause of waste contamination. This method is common in developing countries, such as Indonesia. The open dumping is a waste disposing method which employed without additional barrier beneath and without the leachate collection system [1]. This method induces an uncontrolled leachate deployment which causes groundwater contamination. The Ngipik landfill, located in Gresik - East Java, Indonesia, employs this method since 2002. The landfill has been operated for nearly 17 years and it is currently overloaded. The new landfill area will be constructed nearby the old one. However, the uncontrolled leachate from the open dumping landfill needs to be examined. To figure out the impact of the open dumping landfill in surrounding area, this research uses geophysical methods.
The resistivity and/or electromagnetic geophysical methods are extensively used for detecting geological and geophysical phenomena, including contamination detection and mapping. The previous researchers stated that the electrical resistivity of leachate is lower than the clean water [2-4]; thus, the anomaly can be used to identify the contamination in soil and groundwater.

The VLF-EM is an electromagnetic method, that uses $10-30 \mathrm{KHz}$ bandwidth radio signals from worldwide network transmitter station [4]. Because of the easy operation of the instrument, speed of the field survey and low operation cost, this method is considered as one of the most used among the electromagnetic methods [5]. It is primarily used for the mineral exploration and geological structures' investigation [6,7]. It is also applied for detecting and mapping water contamination $[3,4,8]$.

The electrical resistivity (ER), also known as electrical resistivity tomography (ERT), is 


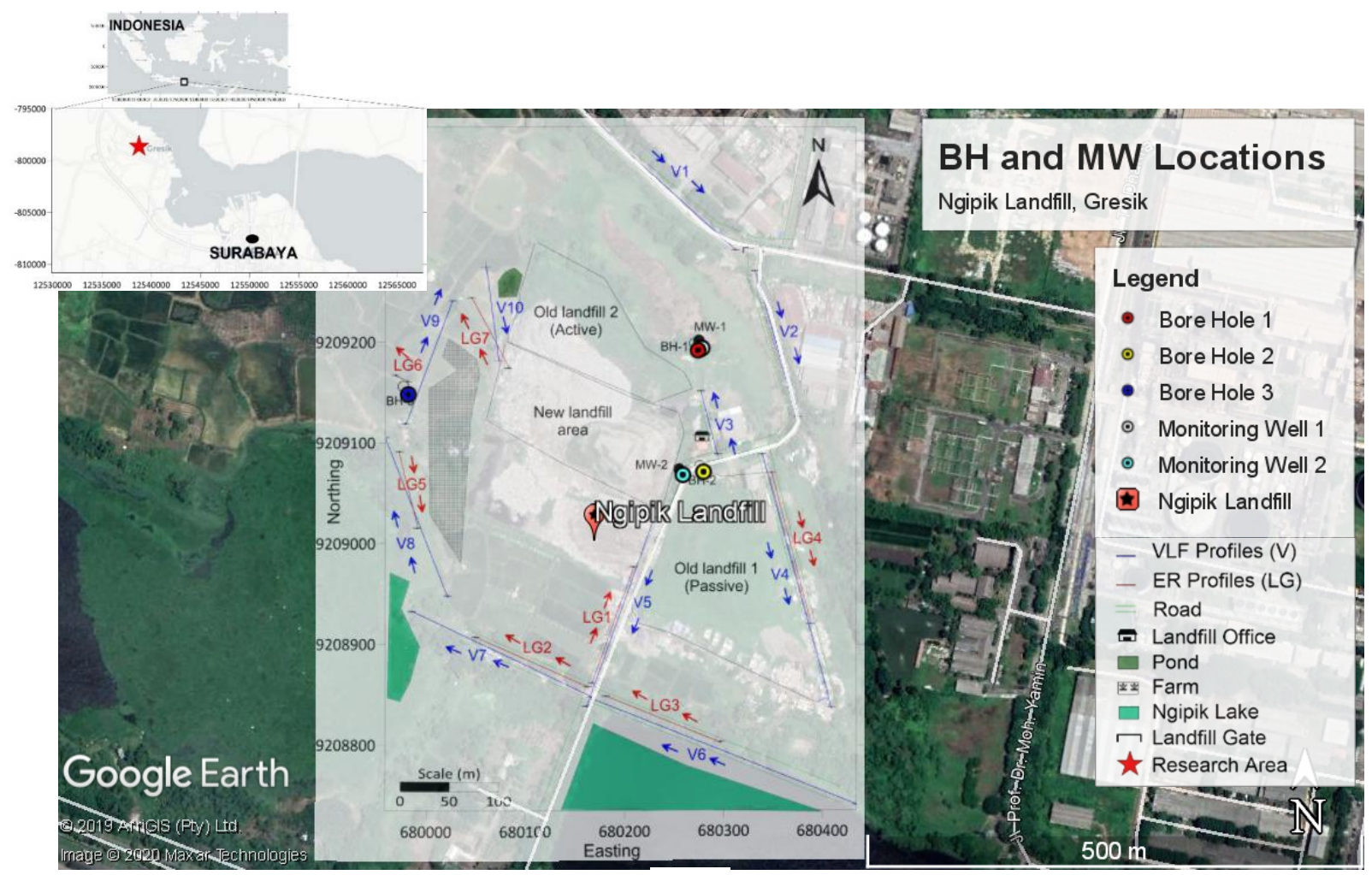

(a)

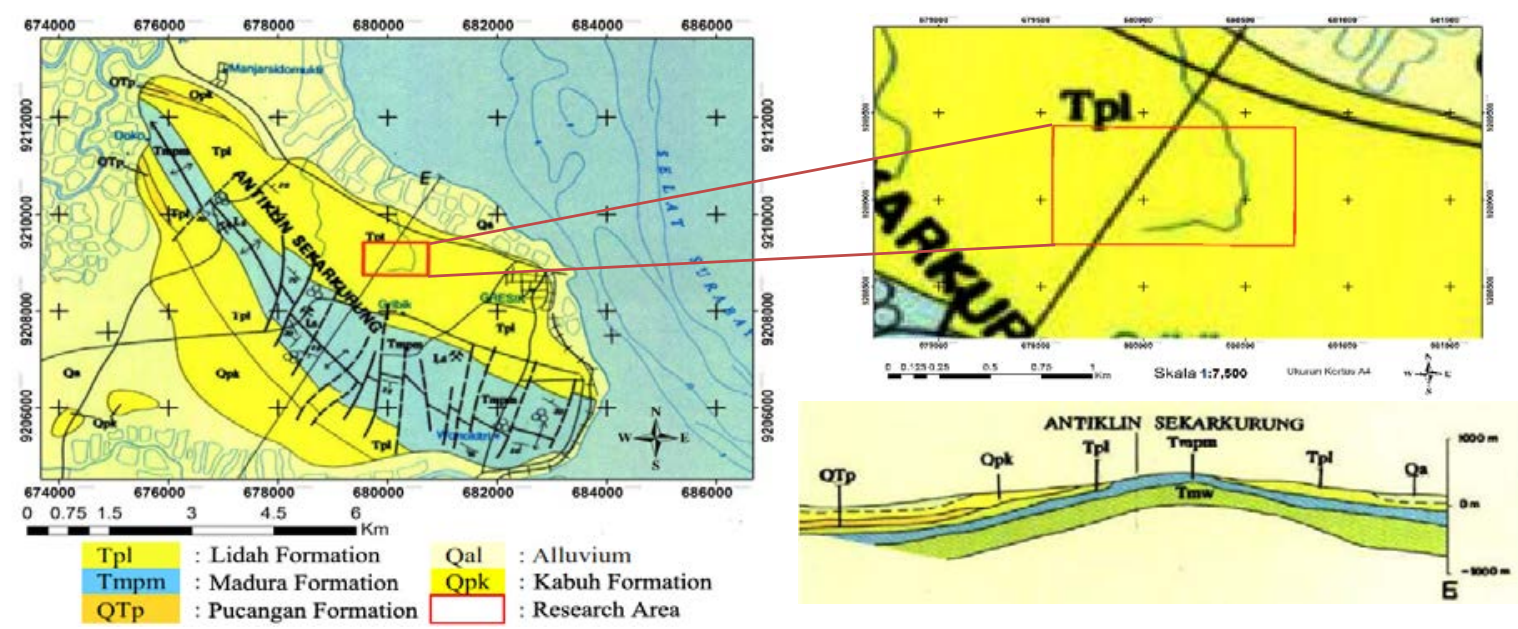

(b)

Figure 1. (a) Location map of Ngipik Landfill site, the bore holes, monitoring wells, VLF-EM and ER profiles. The arrow shows the direction of the measurement; (b) Geological map of Ngipik Landfill region and the E cross section across the investigated area [24]

Table 1. Profiles summary by VLF-EM and ER investigation

\begin{tabular}{ccccccccccc}
\hline Profile & 1 & 2 & 3 & 4 & 5 & 6 & 7 & 8 & 9 & 10 \\
\hline VLF-EM & V1 & V2 & V3 & V4 & V5 & V6 & V7 & V8 & V9 & V10 \\
Length (m) & 180 & 145 & 55 & 250 & 190 & 275 & 200 & 160 & 130 & 95 \\
\hline ER & - & - & - & LG4 & LG1 & LG3 & LG2 & LG5 & LG6 & LG7 \\
Length (m) & - & - & - & 155 & 124 & 124 & 124 & 77.5 & 15.5 & 77.5 \\
$\begin{array}{l}\text { Electrode } \\
\text { space (m) }\end{array}$ & - & - & - & 5.0 & 4.0 & 4.0 & 4.0 & 2.5 & 0.5 & 2.5 \\
\hline
\end{tabular}


conducted by injecting the electric current to earth sublayers and measure the potential difference at some investigated points. This method uses the electrical properties of each sublayer to examine the resistivity variance in earth materials [9]. This method is mainly used for detecting some fissures or holes in the underground layer in relation to the geological structures [10]. The application of ER extended to the environmental pollution investigations, such as investigating the pipeline leak incidents, verify the sewage leakage, and detect the soil contamination [11-14].

While the length of ERT line affects the result of the investigated subsurface depth, the VLF-EM length of line is not affected by the line length because VLF-EM uses the electromagnetic signals while the ERT depends on the electric current by every electrode. However, the use of both methods is to complete the line data since some area of the landfill are inadequate to be installed by the electrodes of ERT. ERT and VLF-EM methods have been conducted by several researchers to map the contamination of an area. However, the study about the contamination during dry and rainy season is limited.

Generally, this work aimed at investigating the leachate deployment in Ngipik landfill, by employing 10 profiles of very low electromagnetic (VLF-EM) method and 7 profiles of electrical resistivity tomography (ERT) investigation (Fig.1a), in the dry and rainy season. For validation purposes, the water quality tests from previous research [15] were analyzed as well. It is necessary to investigate the leachate deployment in the area to assess the risk of open dumping landfill. By instance, there are 10 profiles of geophysical measurement summarized in Table 1. As there are many versions of the leachate resistivity value, the laboratory-scale resistivity measurement is conducted to obtain the resistivity of the soil submerged by the leachate and clean water, as mentioned in the previous research [15]. The result from the laboratory-scale investigation was then used to verify the leachate resistivity on the field.

\section{SITE DESCRIPTION}

The Ngipik landfill is in Gresik regency and lies about $23 \mathrm{~km}$ to the northwest of Surabaya, the capital city of East Java province, Indonesia. The study area is located between $7^{\circ} 9^{\prime} 10.60 "$ South and $112^{\circ} 37^{\prime} 55.41^{\prime \prime}$ East in the international grid (Fig. 1). The area of the domestic waste landfill is nearly 7.4 hectare, including about 1.8 hectares of the new area to be constructed. This landfill served about 1.3 million residents, and it receives 187.42 tons/day domestic wastes [16].

The geological position of the landfill is in Lidah Formation (Fig.1b), which composed of clay, little fossil content and sandstone clay [15] Lidah Formation has a thick clay content on the layer as proven by $30 \mathrm{~m}$ depth drilling gathered in this research. The result indicated that the soil mostly consists of clay and silt $(\sim 51 \%$ and $\sim 44 \%$, respectively) and a little amount of sand ( $4 \%)$, high plasticity (with PI mostly more than $50 \%$ ), and the porosity is around $50 \%$ in average.

This landfill was constructed in 2002 and started its operation in 2003. The construction of the dumpsite was only carried out by digging up twometer depth pit, then piled up the waste without any barrier underneath. The waste mound is placed in the clay soil deposits which was employed without treatment or compaction before the waste dumped. The Ngipik landfill had been operated without a proper leachate collection system, hence the leachate spreads in the surrounding refuse mound (Fig. 2) and - hypothetically- goes directly into the soil and groundwater.

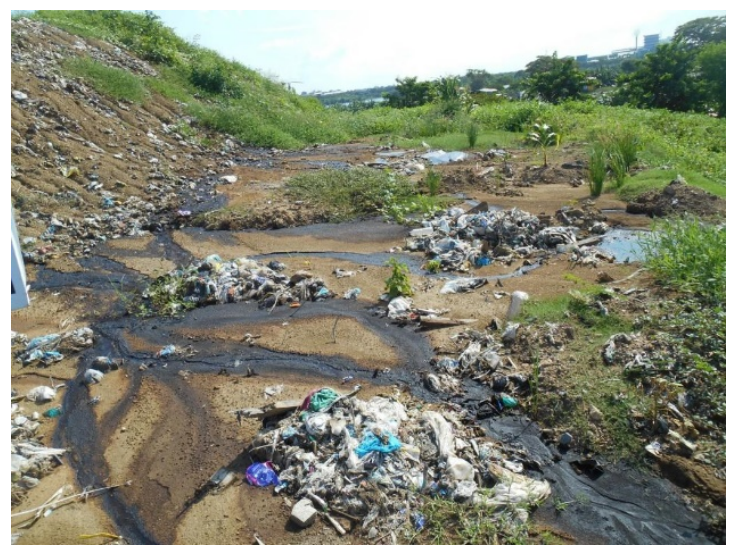

Figure 2. Uncontrolled leachate spreads around the waste mound in Ngipik Landfill

\section{METHODOLOGY}

\subsection{Very Low Frequency - Electromagnetics (VLF-EM)}

A total of 10 profiles with 5 meters of station to station distance was conducted for leachate deployment mapping in Ngipik landfill. The profile length varies between 55 and 275 meters from V1 to V10 (Fig. 1). The summary of the profiles conducted with each method is listed in Table 1. The measurement was conducted in the landfill area around the waste mound, because it is impossible to do the investigation through the waste mound, which reaches the height of about 12 meters without the soil covering.

After gathering the field measurement data, the VLF-EM data is interpreted with several filters to remove the noise and disturbance to the electromagnetic waves. The VLF-EM uses a very low frequency (around $20 \mathrm{kHz}$ ); hence, the data is very sensitive to the geologic noise. The geologic noise depends on the complexity of the causative 
geologic structure. Therefore, the noise is impossible to remove by the conventional filtering techniques [17]. In this research, the VLF-EM data is filtered with noise assisted - multivariate empirical mode decomposition (NA-MEMD), to increase the accuracy of the signal from the VLFEM data, and to remove the noises. The data was then filtered with Fraser, Karous-Hjelt filtering and inversion. The last step is the interpretation of the data present in the 2D layout in this paper.

\subsection{Electrical Resistivity Tomography (ERT)}

The ERT method is based on the measuring of the electrical resistivity distribution to the subsurface, using current transmitting into the ground by two electrodes ( $\mathrm{A}$ and $\mathrm{B}$ ), and measures the potential difference between the second pair of the electrodes ( $\mathrm{M}$ and $\mathrm{N}$ ) [18]. By nature, different materials have different electrical properties. This method can describe the underground environment [14]. The electrical penetration is proportional to the separation between the electrodes and provide information about the stratification of the ground [19]. This study uses 7 profiles of ER investigation with 2.5 and 5.0 meters distance between the electrodes. The length of the profiles varies from 15.5 to 155 meters from LG1 to LG7. The shortest profile, LG6 is conducted near the Bore Hole - 3, $B H-3$. The LG6 has difficulty to obtain longer profile because of the site condition. Thus, this profile, the shortest one, taken with the distance of the electrodes of 0.5 meter. The profiles' length, investigated with both methods, can be observed in Table 1.

Several electrode arrays are available for subsurface resistivity studies, such as dipole-dipole, pole-pole, Wenner, and Schlumberger arrays. The arrays' selection depends on the geology, the depth of investigation, and field feasibility. The type of array can also influence the final resistivity image, because each array has different sensitivity, depth of investigation, and resolution power [20]. The combination of Wenner and Schlumberger is used in this study, for both laboratory-scale resistivity measurement and field investigation, because the Wenner-Schlumberger array maps the lateral resistivity distribution in the homogeneous subsurface and are able to detect the inhomogeneity of the sublayers [21]. Other researchers conducted several arrays of the ER method for their study and found that Wenner-Schlumberger array has lower error rate data [14]. For the last step for smoothing the data, this study uses RES2DINV from ABEM Instruments (1998) to process the apparent resistivity gathered from field investigation and to interpret the ER data.

\subsection{Water Quality Sampling and Analysis}

Samples were collected from monitoring well, $M W$ and bore hole, $B H$ around the landfill. MW-1 and $\mathrm{MW}-2$ are the monitoring well of Ngipik landfill, $\mathrm{BH}-1$ and $\mathrm{BH}-2$ are the bore hole where the soil sample were taken next to the monitoring wells (Fig. 1). BH-3 is taken about 200 meters from the waste mound to investigate how far the leachate deployed. Water samples were collected twice on August 2016 (dry season) and January 2017 (rainy season). Water quality test is also conducted on field by using $\mathrm{pH}$ Meter by CONSTANT instrument.

\subsection{Laboratory-Scale Electrical Resistivity Test}

The Laboratory-scale electrical resistivity test was conducted to obtain the resistivity value of soil with leachate content, and another one with water content. There are two soil samples: a soil sample submerged by leachate and another one submerged by clean water. The samples were observed with electrical resistivity test by using WennerSchlumberger arrays in tube sample with diameter $3.72 \mathrm{~cm}$ and high $7.27 \mathrm{~cm}$, for several liquid contents. Then, as ERT test, the data modulated using RES2DINV from ABEM Instruments (1998).

\section{RESULTS AND DISCUSSION}

In laboratory-scale resistivity test, the resistivity of the clay soil submerged by the landfill leachate is less than 2.5 ohm-m, while for the submerged one with the clean water, the resistivity is higher in around $2.5 \mathrm{ohm}-\mathrm{m}$ to $3.5 \mathrm{ohm}-\mathrm{m}$ (Fig. 3). This result corresponds to the previous research, that the resistivity of soil submerged by the leachate is lower than that of the clean water. The organic and inorganic chemicals in the leachate increase the total dissolved solids in the rock's pore fluid, then it decreases the resistivity of the sublayer $[2,4,22]$. The clean water submerged soil reach stable value when the clean water content is $33.5 \%$ while the leachate content is around $32 \%$. Viscosity of leachate is mostly higher than water, yet the viscosity does not significantly affect the velocity of the liquid in groundwater as reported in [22]. 


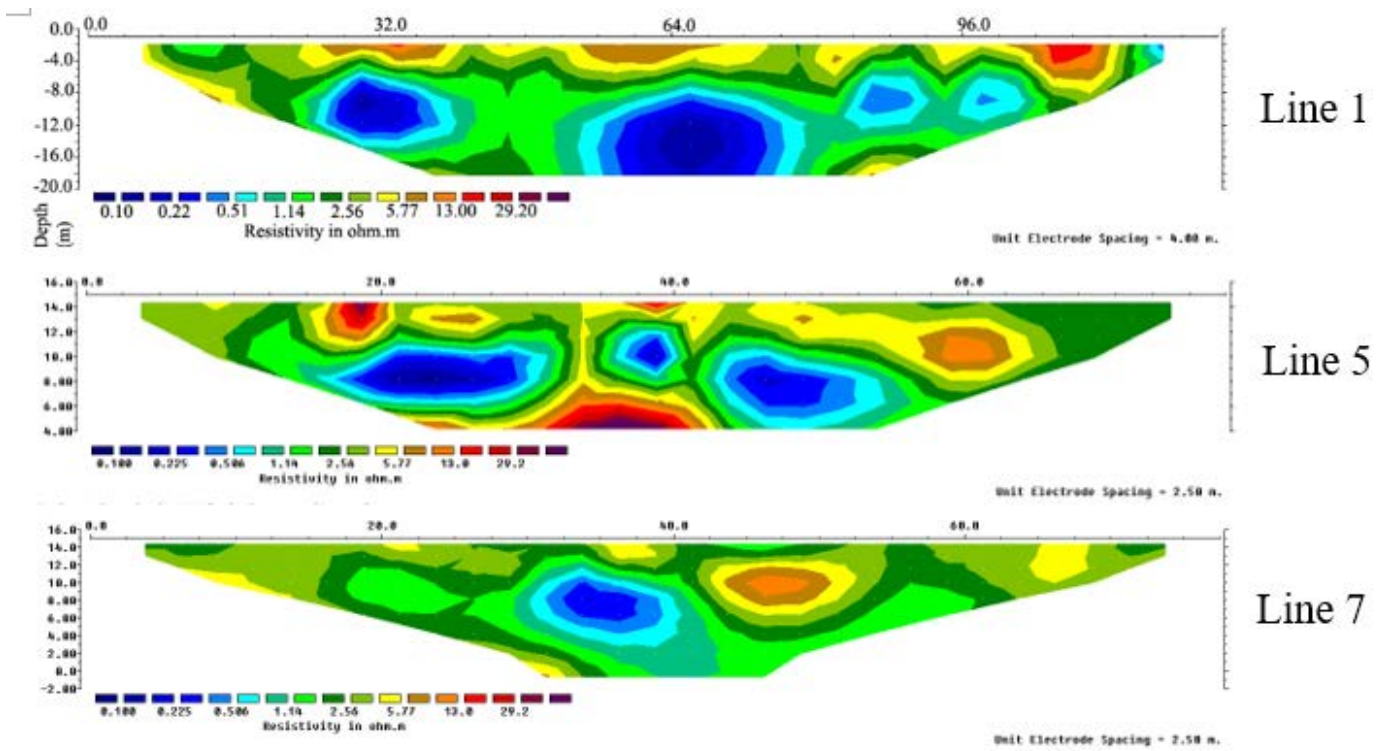

(a)

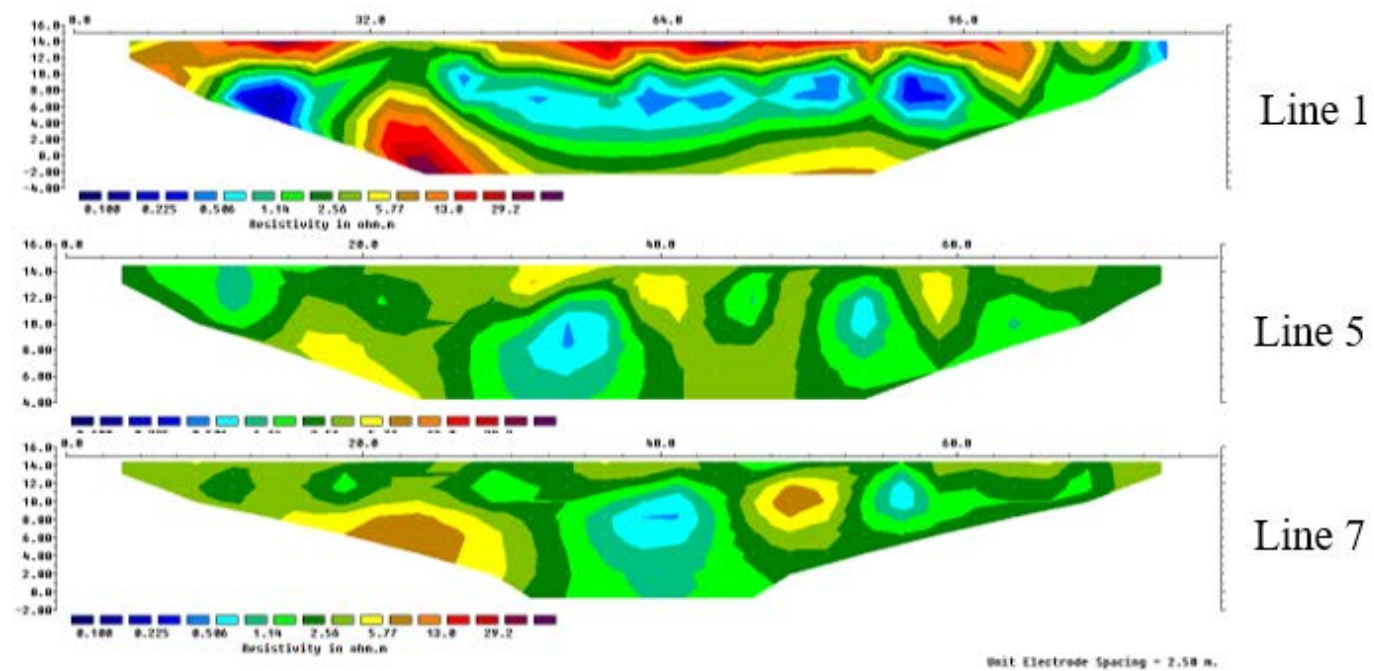

(b)

Figure 4. (a) Subsurface condition of ERT investigation on dry season; (b) Subsurface condition of ERT investigation on rainy season

Table 2. Water contents by pH-meter measurement on field

\begin{tabular}{ccccc}
\hline Sample & $\mathrm{pH}$ & $\begin{array}{c}\text { Conductivity } \\
(\mathrm{mS} / \mathrm{cm})\end{array}$ & $\begin{array}{c}\text { TDS } \\
(\mathrm{ppm})\end{array}$ & $\begin{array}{c}\text { Salinity } \\
(\mathrm{ppm})\end{array}$ \\
\hline East lake & 7.38 & 0.884 & 590 & 421 \\
West lake & 7.29 & 0.966 & 636 & 460 \\
MW-2 & 7 & 6.320 & 4450 & 3340 \\
MW-1 & 6.95 & 3.110 & 2080 & 1460 \\
Leachate & 8.2 & 11.570 & 7430 & 5750 \\
\hline
\end{tabular}




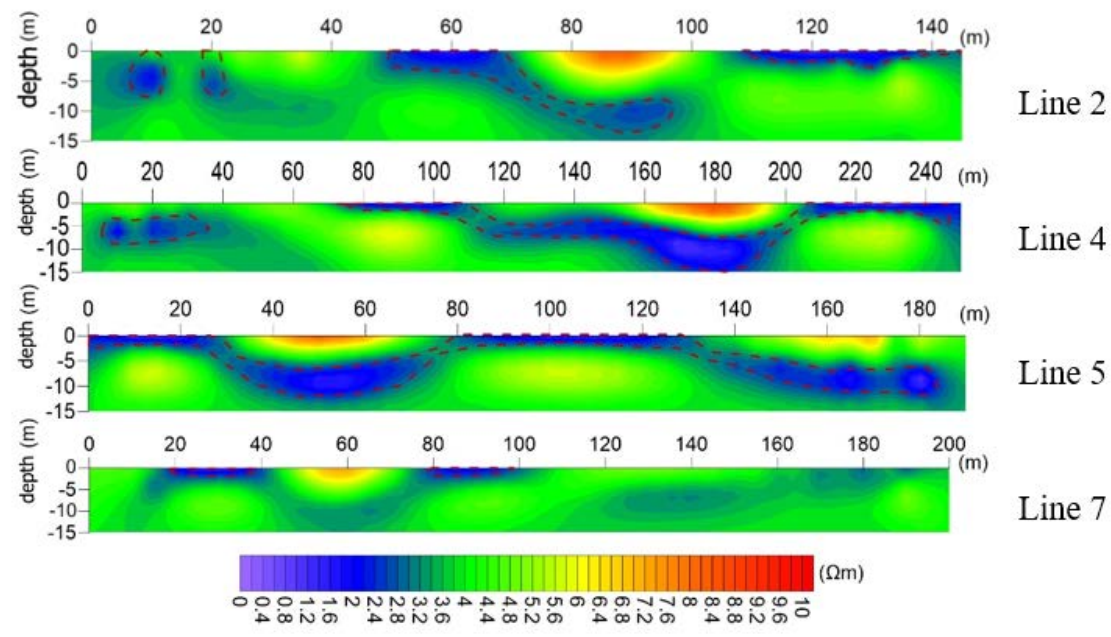

(a)

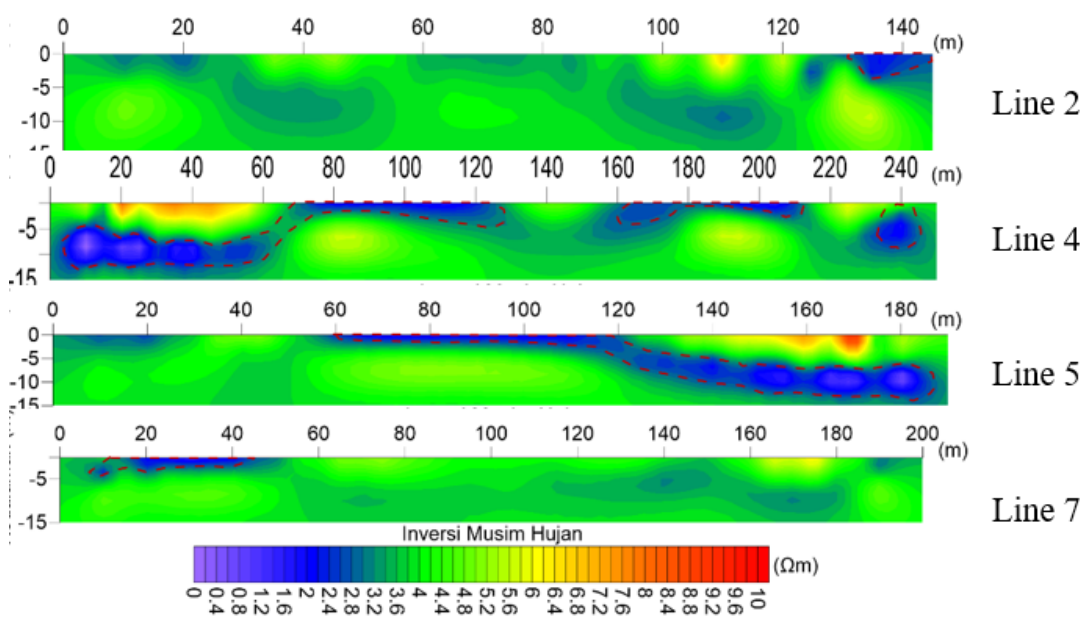

(b)

Figure 5. (a) Subsurface condition of VLF-EM investigation on dry season; (b) Subsurface condition of VLFEM investigation on rainy season

Moreover, water which has the lower viscosity, assumed to need more weight to stabilize the resistivity value in the soil rather than leachate. The low resistivity resulted in high conductivity. This is proved as well by the conductivity test towards the landfill leachate on the field. The conductivity of leachate is $11.57 \mathrm{mS} / \mathrm{cm}$, while the conductivity of clean water from the surrounding lakes are below 1 $\mathrm{mS} / \mathrm{cm}$ (Table2).

The low resistivity data are shown in dark blue color. The brighter the color, the higher the resistivity of the survey area. The result of electrical resistivity tomography, ERT investigation shows that several lines have leachate deployment to a maximum depth of 20 meters, as observed on Line 1 of ERT, $L G$ 1, on the dry season (Fig. 4a). LG 1 is located between the old and new landfill (15 $\mathrm{m}$ in the northwest and $60 \mathrm{~m}$ in the northeast direction, respectively). However, on the rainy season (Fig. $4 \mathrm{~b}$ ), the leachate showed in blue color scattered and covered in a light blue color, which indicates that the resistivity is increasing in rainy season. Line 5 (LG 5) is located next to the new landfill (100 $\mathrm{m}$ in the southwest direction), which also has the same pattern from dry and rainy seasons, especially, dark 

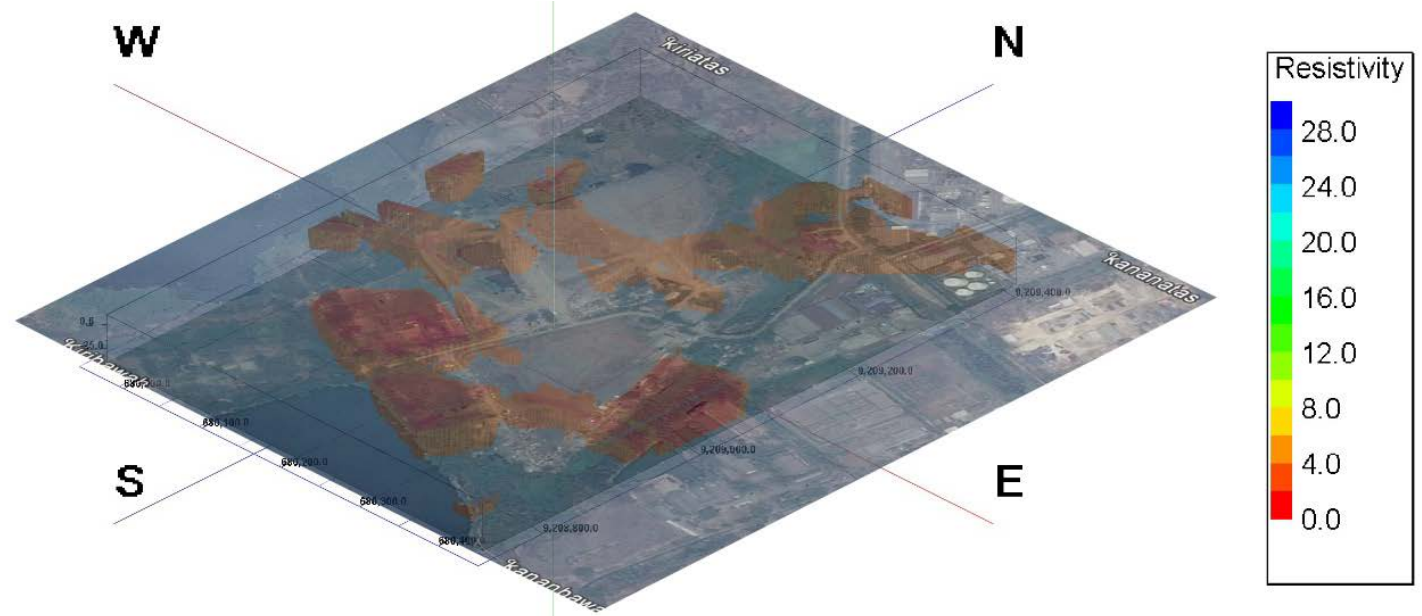

Figure 7. 3D image of leachate mapping on dry season in Ngipik Landfill
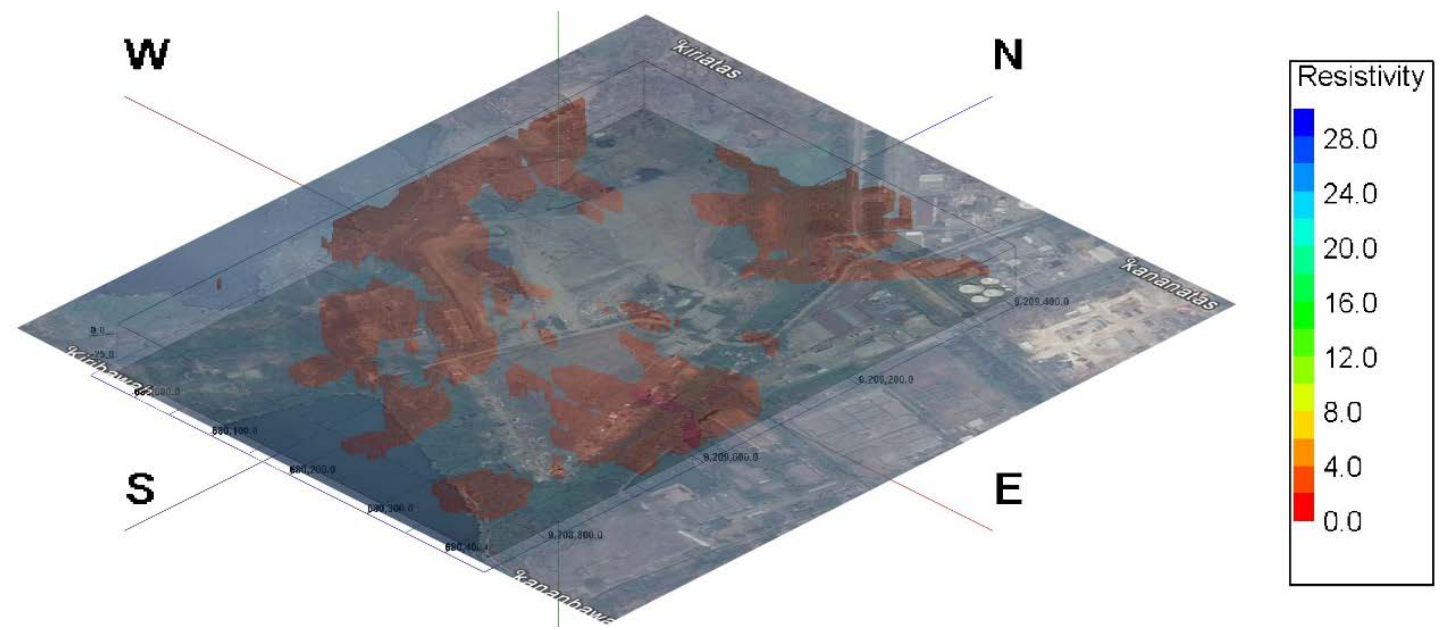

Figure 8. 3D image of leachate mapping on rainy season in Ngipik Landfill

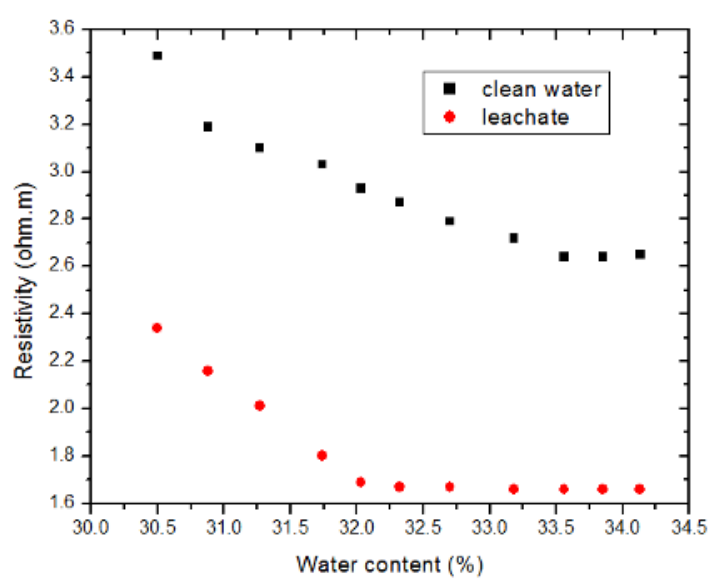

Figure 3. Resistivity correlation with water content for soil submerged by clean water and leachate [15]

blue color in dry season in around $12 \mathrm{~m}-15 \mathrm{~m}$ depth and light blue color in rain season. Line 7 (LG 7), located on the west side of the active and new landfill (10 $\mathrm{m}$ in the west directions), also has the same pattern between the dry and rainy season especially on $6 \mathrm{~m}-10 \mathrm{~m}$ depth. It is agreed with the
VLF-EM investigation results, that the blurring dark blue color (or light blue color) means that the resistivity of the investigated area is increasing, as shown in line 2, line 4, line 5, and line 7 of rainy (Fig. 5b) and dry seasons (Fig. 5a). All the investigated area has leachate on them, based on the VLF-EM investigation.

The area has a shallow water table. The depth of water table in rainy season is around $-0.50 \mathrm{~m}$ from the ground surface. The leachate, that disappears from the ERT investigation in wet season, is assumed to be caused by its dilution by the rainwater, so that the resistivity increases. This is supported by the conductivity data on the field, that the increase in resistivity decreases the conductivity (Fig. 6). Previous researcher describes the dilution process of leachate in groundwater and confirms the quality of leachate decreases in wet season as reported in [23].

The 3D images are interpreted from ERT and VLF-EM investigations on rainy and dry seasons by interpolating the data on all lines. In the dry season, 
Table 3. Water and leachate contents

\begin{tabular}{lllllllll}
\hline No & Parameters & Unit & BH-1 & MW-2 & BH-3 & Leachate & 1 & 2 \\
\hline 1 & pH & - & 7.15 & 7.35 & 7.75 & 8.05 & $6-9$ & $6-9$ \\
2 & TSS & mg/L & 20 & 202 & 90 & 280 & 400 & 100 \\
3 & TDS & mg/L & 3040 & 1380 & 860 & 3750 & 4000 & - \\
4 & $\mathrm{COD}$ & $\mathrm{mg} / \mathrm{L} \mathrm{O}_{2}$ & 44 & 44 & 24 & 2480 & 300 & 300 \\
5 & $\mathrm{BOD}$ & $\mathrm{mg} / \mathrm{L} \mathrm{O}_{2}$ & 25 & 26 & 14 & 1512 & 150 & 150 \\
6 & Nitrite & $\mathrm{mg} / \mathrm{L} \mathrm{NO}_{2}-\mathrm{N}$ & 0.921 & 6.241 & 0.135 & 1006 & 3 & - \\
7 & Nitrate & $\mathrm{mg} / \mathrm{L} \mathrm{NO}_{3}-\mathrm{N}$ & 8.8 & 6.15 & 0.86 & 1058 & 30 & - \\
8 & Ammonia & $\mathrm{mg} / \mathrm{L} \mathrm{NH}_{3}-\mathrm{N}$ & 1.53 & 127.25 & 26.85 & 1020.44 & 5 & - \\
9 & Total N & $\mathrm{mg} / \mathrm{L} \mathrm{NH}-\mathrm{N}$ & 11.25 & 140.35 & 27.84 & 1031.02 & - & 60 \\
10 & Cadmium & mg/L Cd & 0.04 & 0.04 & 0.04 & 0.08 & - & 0.1 \\
\hline 1 & Indonesian Ministry of Public Works Regulation No.3, 2013 & & \\
2 & Indonesian Ministry of Environment and Forestry No.59, 2016 Regulation &
\end{tabular}

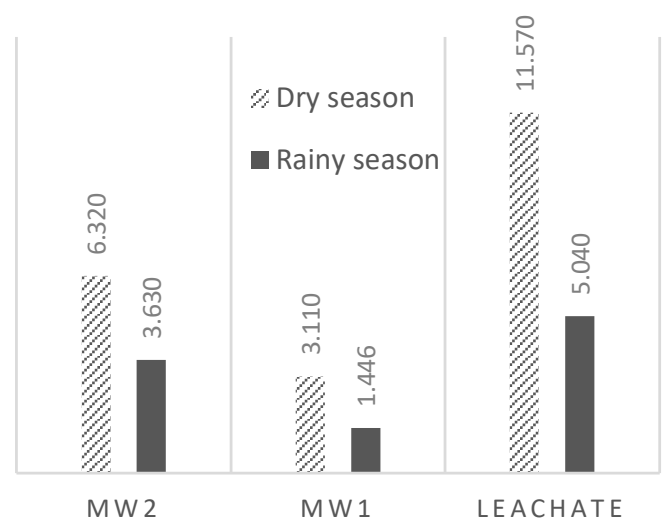

Figure 6. Conductivity $(\mu \mathrm{S} / \mathrm{cm})$ of water sample on rainy and dry Season

the leachate plume was seen below the waste mound (Fig. 7), while in the rainy season, the leachate was seen in the surrounding landfill area. It is assumed that the rainfall runoff around the waste mound and caused the leachate spread around the landfill area (Fig. 8), instead of under the waste mound. Hence hypothetically, in the wet season, the water table rise and increases the hydraulic conductivity of the soil under the landfill; Induce the water stuck under the refuse pit then the leachate plume will spread in the groundwater. This phenomenon called water mounds [23].

To prove the deployment data from the VLFEM and ER investigations, water and leachate investigations were conducted. The water samples were taken from the bore hole, $\mathrm{BH}$ and monitoring well, $M W$ around the landfill area. There are $\mathrm{BH}-1$, BH-3, MW-1, MW-2, and Ngipik lake as well (Fig. 1). Table 3 shows the result of the water investigation from laboratory and Indonesian regulations, for the contents of water allowed to be discharged in the ground. Two Indonesian regulations are stated in the table to give a full assessment of the water quality, because some parameters are not regulated in another regulation, such as cadmium, nitrite, nitrate, ammonia, and total dissolved solids (TDS). The new regulation, 2, gives a lower limit for total suspended solid (TSS), which is $100 \mathrm{mg} / \mathrm{l}$ but does not mention the limitation for TDS. Some parameters of leachate have already exceeded the regulation, and many others nearly exceed the limitation. The chemical oxygen demand (COD) and biochemical oxygen demand (BOD) of the leachate, $2480 \mathrm{mg} / \mathrm{l}$ and 1512 $\mathrm{mg} / \mathrm{l}$ respectively, have exceeded the limitation by both regulations many fold the acceptable value. The nitrate and ammonia contents also exceeded the allowable concentration. Other parameters, such as TSS, TDS, and cadmium has close value to the limitation (Table 3).

The water quality of $\mathrm{BH}-3$ has better quality than that of other water samples, for example, the TDS, COD, BOD, nitrite, and nitrate values are less than the $\mathrm{BH}-1$ and $\mathrm{BH}-2$. The $\mathrm{BH}-3$ is located far from the waste mound; hence, the $\mathrm{BH}-3$ hypothetically has been less influenced by the leachate contamination. This is agreed by the data of ERT investigation on Line 6 (Fig. 5), which was observed not to detect any leachate. Line 6 is located 0.5 meter from $\mathrm{BH}-3$ and has 15.5 meters of length. Hence, the result of Line 6 could represent the contamination in $\mathrm{BH}-3$. This also proves that the ERT is reliable as the leachate plume investigation on the landfill area.

The contents of water samples from BH-1, MW2 , and $\mathrm{BH}-3$ have close value to the contents of the leachate, such as TSS of MW2, TDS of BH-1, nitrite, and ammonia of $\mathrm{MW}-2$ and $\mathrm{BH}-3$ have even exceeded the regulations (Table 3 ). To ensure the result, water quality measurements were conducted in the field as well by using the water $\mathrm{pH}$-meter. The sample is taken from MW-1, MW-2, West and East lakes, and the leachate itself. The results show that the conductivity, TDS, and salinity of MW-2 have a close value to the leachate. Even the result of MW-1 was not as close as the MW-2 in terms of the leachate, but the parameters have already increased to almost one-third of the leachate contents (Table 3). It indicates that water from the site has been 

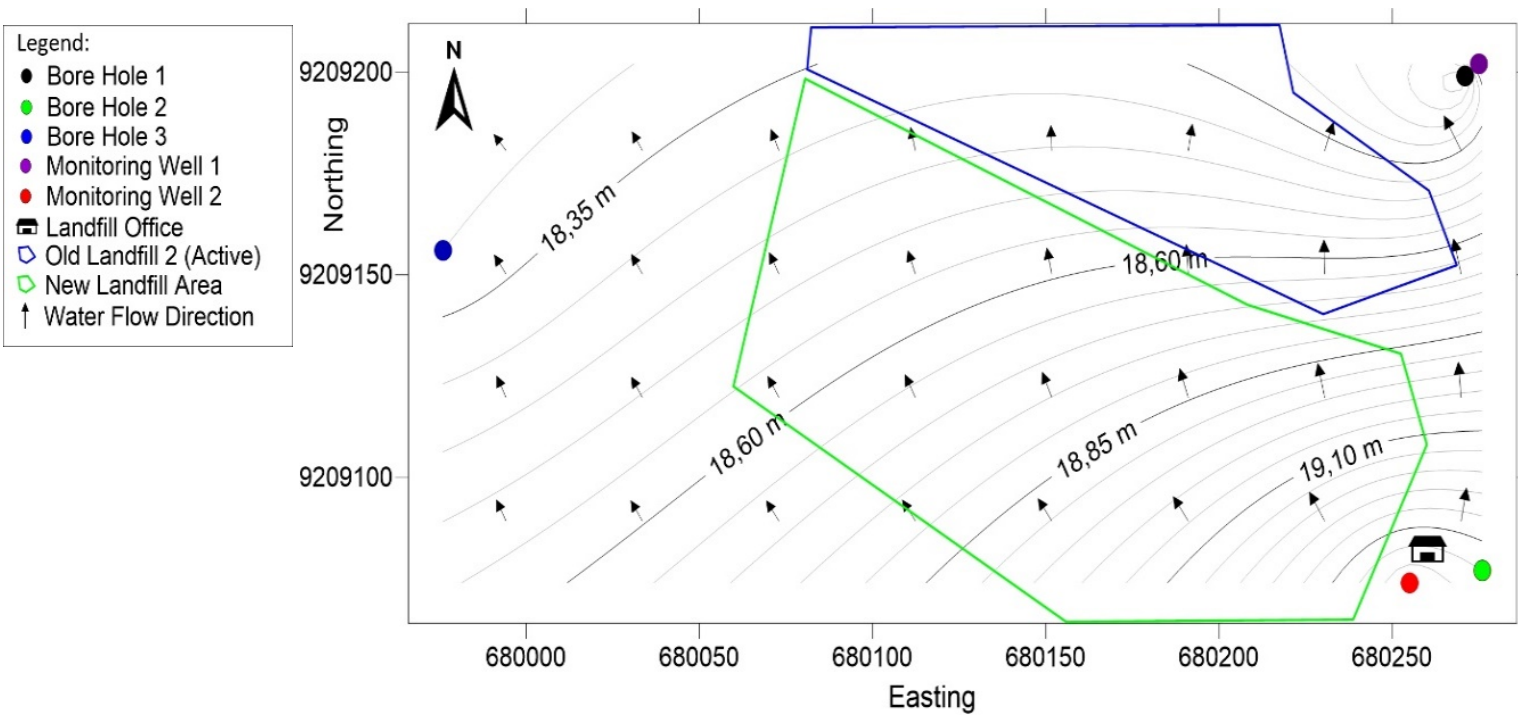

Figure 9. Local flow net map of unconfined aquifer (water table) based on wells in the study area

affected by the leachate contents. These results confirm the geophysical investigation, that the landfill area has been deployed by the leachate from the landfill.

The water samples from the lakes have quite different results from the leachate contents. This is suitable for the results from the VLF-EM investigations in line 7 , that there is no leachate deployment around the lake, because the groundwater flows from the lake to the landfill area (Fig.9).

\section{CONCLUSION}

The VLF-EM and ER investigations were combined well in this research and gave the supporting data in the results successfully. The results completed one and another method conducted in this research, because the leachate has plumed up to 21 meters depth in the ER investigation, completing the maximum 15 meters limitation of VLF-EM data result. The water quality tests agree well with the geophysical result, because the water content from MW-2, the nearest well from the landfill, almost approaches the leachate contents, which proves that the leachate has affected water quality from the wells. This indicates that the clay deposits beneath the landfill without any improvement are not enough to retain the leachate plumes. In summary, the wet season spreads the leachate around the waste mound by the shallow water table. Even though there is a dilution potential, the groundwater contamination is at the high risk. In dry season, the high-quality leachate seeps under the waste mounds. Then the soil is at the high risk of contamination. Therefore, an appropriate subsurface improvement should be assessed in the future research.

For first countermeasures of the Ngipik Landfill area, the leachate collection system is highly recommended. Leachate then should be concentrated and processed in leachate pond. The open dumping method should be strictly banned, because of the environmental pollution effects, that have been explained by the results of this study.

\section{ACKNOWLEDGMENTS}

This paper is part of the research funded by Ministry of Research, Technology, and Higher Education of Indonesia, Ristekdikti, by PMDSU Program (Pendidikan Magister Menuju Doktor untuk Sarjana Unggul/ The Education of Master's Degree Leading to Doctorate Degree for Excellent Undergraduates). The authors express great gratitude to the PMDSU program from Ristekdikti. They also would like to extend their gratitude to the government of Gresik regency, especially the Gresik Sanitary Office and Ngipik Landfill office, for the cooperation during the research.

\section{REFERENCES}

[1] E. P. Agency, "Landfill Manuals: Landfill Site Design." Ireland: Environmental Protection Agency, 2000.

[2] S. Park, M. J. Yi, J. H. Kim, and S. W. Shin, "Electrical resistivity imaging (ERI) monitoring for groundwater contamination in an uncontrolled landfill, South Korea,” J. Appl. Geophys., vol. 135, pp. 1-7, 2016.

[3] A. K. Benson, "Mapping groundwater contamination using dc resistivity and VLF geophysical methods-A case study," Geophysics, vol. 62, no. 1, pp. 80-86, 1997. 
[4] F. A. Monteiro Santos, A. Mateus, J. Figueiras, and M. A. Gonçalves, "Mapping groundwater contamination around a landfill facility using the VLF-EM method - A case study,” J. Appl. Geophys., vol. 60, no. 2, pp. 115-125, 2006.

[5] E. Al-Tarazi, J. Abu Rajab, A. Al-Naqa, and M. El-Waheidi, "Detecting leachate plumes and groundwater pollution at Ruseifa municipal landfill utilizing VLF-EM method,” J. Appl. Geophys., vol. 65, no. 3-4, pp. 121-131, 2008.

[6] P. Ligas and M. Palomba, "An integrated application of geological-geophysical methodologies as a cost-efficient tool in improving the estimation of clay deposit potential: Case study from South-Central Sardinia (Italy),” Ore Geol. Rev., vol. 29, no. 2, pp. 162-175, 2006.

[7] V. R. Babu, S. Ram, and N. Sundararajan, "Modeling and inversion of magnetic and VLFEM data with an application to basement fractures: A case study from Raigarh, India,” Geophysics, vol. 72, no. 5, pp. B133-B140, 2007.

[8] A. I. Ammar and S. E. Kruse, "Resistivity soundings and VLF profiles for siting groundwater wells in a fractured basement aquifer in the Arabian Shield, Saudi Arabia,” J. African Earth Sci., vol. 116, pp. 56-67, 2016.

[9] W. M. Telford, G. LP, and R. E. Sheriff, Applied geophysics. Cambridge: Cambridge university press, 1990.

[10] J. Poisson, M. Chouteau, M. Aubertin, and D. Campos, "Geophysical experiments to image the shallow internal structure and the moisture distribution of a mine waste rock pile,” J. Appl. Geophys., vol. 67, no. 2, pp. 179-192, 2009.

[11] E. A. Ayolabi, A. F. Folorunso, and S. S. Idem, "Application of Electrical Resistivity Tomography in Mapping Subsurface Hydrocarbon Contamination,” Earth Sci. Res., vol. 2, no. 1, pp. 93-104, 2012.

[12] A. T. Batayneh, "2D Electrical Imaging of an LNAPL Contamination, Al Amiriyya Fuel Station, Jordan,” J. Appl. Sci., vol. 5, no. 1, pp. 52-59, 2005.

[13] P. Martinez-Pagan, A. F. Cano, G. R. Ramos da Silva, and A. B. Olivares, "2-D Electrical Resistivity Imaging to Assess Slurry Pond Subsoil Pollution in the Southeastern Region of Murcia, Spain,” J. Environ. Eng. Geophys., vol. 15, no. 1, pp. 29-47, 2010.

[14] Wang T.P., Chen C.C., Tong L.T., Chang P.Y., Chen Y.C., Dong T.H., Liu H.C., Lin C.P., Yang K.H., Ho C.J. and Chen S.N., “Applying
FDEM, ERT and GPR at a site with soil contamination: A case study,” J. Appl. Geophys., vol. 121, pp. 21-30, 2015.

[15] R. A. A. Soemitro, D. D. Warnana, and N. Sutra, "Characterization of leachate distributions at Ngipik Municipal Solid Waste Disposal site,” Geotech. Eng. J. SEAGC, 2018.

[16] U. A. Agustina and I. Warmadewanthi, "Pengaruh Resirkulasi Lindi terhadap Laju Degradasi Sampah di TPA Ngipik, Gresik; Effect of Leachate Recirculation on Solid Waste Degradation Rate in Ngipik Landfill , Gresik,” in Scientific Conference IX Environmental Technology, 2012, no. July, pp. 6-11.

[17] Y. Jeng, M. Lin, C. Chen, and Y. Wang, "Noise reduction and data recovery for a VLFEM survey using a nonlinear decomposition method,” Geophysics, vol. 72, no. 5, pp. F223F235, 2007.

[18] M. Bayrak and L. Şenel, "Two-dimensional resistivity imaging in the Kestelek boron area by VLF and DC resistivity methods," J. Appl. Geophys., vol. 82, pp. 1-10, 2012.

[19] T. Dahlin, “The development of DC resistivity imaging techniques,” Comput. Geosci., vol. 27, no. 9, pp. 1019-1029, 2001.

[20] F. Nguyen, S. Garambois, D. Chardon, D. Hermitte, O. Bellier, and D. Jongmans, "Subsurface electrical imaging of anisotropic formations affected by a slow active reverse fault, Provence, France,” J. Appl. Geophys., vol. 62, no. 4, pp. 338-353, 2007.

[21] J. M. Reynolds, An introduction to applied and environmental geophysics. John Wiley \& Sons, 2011.

[22] D. D. Lopes, S. M. C. P. Silva, F. Fernandes, R. S. Teixeira, A. Celligoi, and L. H. Dall'Antonia, "Geophysical technique and groundwater monitoring to detect leachate contamination in the surrounding area of a landfill - Londrina (PR - Brazil),” J. Environ. Manage., vol. 113, pp. 481-487, 2012.

[23] T. H. Christensen, P. Kjeldsen, P. L. Bjerg, D. L. Jensen, J. B. Christensen, A. Baun, H. Albrechtesen, and G. Heron, "Biogeochemistry of land ${ }^{\circledR}$ ll leachate plumes,” Appl. Geochemistry, vol. 16, pp. 659-718, 2001.

[24] Sukardi, "Peta Geologi Lembar Surabaya \& Sapulu, Jawa,” Bandung, 1992.

Copyright (C Int. J. of GEOMATE. All rights reserved, including the making of copies unless permission is obtained from the copyright proprietors. 